\author{
ANNA GAWARECKA \\ Uniwersytet im. Adama Mickiewicza w Poznaniu \\ ORCID: 0000-0002-0930-0064 \\ e-mail: gawarecka@gazeta.pl
}

\title{
WHY OVID? POSTMODERN ALTERNATIVE BIOGRAPHIES OF THE GREAT POET
}

\begin{abstract}
Gawarecka, Anna, Why Ovid? Postmodern Alternative Biographies of the Great Poet (Dlaczego Owidiusz? Postmodernistyczne biografie alternatywne wielkiego poety)

Article analyses a literary portrait of Publius Ovidius Naso in the novels Naso the Poet (1969) by Jacek Bocheński, An Inexplicable Story or the Narrative of Questus Firmus Siculus by Josef Škvorecky (1998) and The Last World. A Novel with an Ovidian Repertory by Christoph Ransmayr (1988).
\end{abstract}

Keywords: exile of Ovid; historical metafiction; intertextuality; actualization of ancient tradition; counterfactual fiction.

\begin{abstract}
"One needs someone on a grand scale, of reputation, someone written with capital letters, indeed SOMEONE, style requires a PERSON, and this person must induce noise, exactly, you want a PERSON with NOISE, applauded by the people, whose name has been heard again and again, hundreds of thousands of times repeated and given further, please be prepared then, I will say the name, attention! attention!, I feel you have stopped breathing, it is quiet, general tension - OVID!"”
\end{abstract}

In the novel entitled Naso the Poet (1969), Jacek Bocheński introduces his titular character with the above-quoted words, however, he precedes this literary stage entrée with a series of commentaries and justifications proving the rightness of perceiving Ovid as a star of mass culture, which remains a significant hallmark of the twentieth century. The author of Ars amandi is thus presented here as a famous illusionist and trickster or, perhaps, taking into account his complicated relationship with Octavian, as a jester ${ }^{2}$, described by

\footnotetext{
${ }^{1}$ Bocheński 2009: 12

${ }^{2}$ The validity of such suggestion is confirmed, on the one hand, by the date of the text's publication, leading the reader on the trail of political interpretation of the novel, and, on the other, by the attributes of jester described by Kołakowski (1989: 178, 180): "Philosophy of jesters is the one which in every age unmasks what is regarded as the most stable, and reveals doubts
} 
Leszek Kołakowski in his well-known essay, who keeps hiding traces of his real sensations and experiences behind the conventions of poetic imagery. The subject of the spectacle is his fate barely reconstructed by the narrator, who puts on a mask of announcer in order to denude these conventions by finding in them autobiographical signals, and to expose those aspects of Ovid's life which might be attractive and still interesting from the view-point of the modern recipient. For this reason, Bocheński puts in the foreground various "spicy details" exposing the secrets of an ancient alcove and the mystery of the poet's exile to Tomis, of which causes have remained unknown until today. In both the cases, as the biographist hidden behind his narrator at least suggests, the creative strategies of popular literature (culture) seem helpful, since on the one hand they allow Bocheński to "bring" the portrayed creator closer to the twentieth-century audience, and, on the other, they correspond to the conviction declared in the novel according to which:

None of us in person are not in the past, that is, in what it was. To be aware of the past, in which we are not, is possible, however, only now, where we are, and where we can express the past with the style and words given us in the present. I tell admittedly "it was," but this "it was" does not have any perceived existence, "it was" exists for you insofar as I am saying "it was," which makes "it was" rendered by myself to reveal properly as "it is." Hence an important conclusion: there is no practical difference between the past and the present. The ancient history is happening today. ${ }^{3}$

From the contemporary point of view, this opinion does not require any deepen or far-reaching justification, since, after the arrangements of Hayden White and the new interpretation of Nietzsche's philosophy, a "textual" way of existence of the past, mediated by documents and fiction (not only in the language sense), does not seem to raise any doubts. In the ' 60 s., however, such an attitude, which might be described as postmodern avant la lettre, to the issue of the so-called historical truth consisting de facto in questioning the possibility of its "objective" reconstruction was, at least in conditions of the then Polish culture, a risky abuse exposing the author to charges of anachronization of the presented reality, and, what was perhaps more important, arousing caution (not without reason) of the cenzorship which was looking for traces of Aesop discourse between the lines of the historical narrative, published - as Bocheński recalls after years in his

and contradictions of what seems evident and indisputable, turns the obviousness of common sense into a mockery, and proves its point in absurd [...]. The attitude of the jester is a constant effort of reflection over possible rights of opposing ideas, hence it is dialectic from nature; it is simply overcoming what is [...], it is ruled, after all, not by the urge of defy, but mistrust of the all stabilized world. In the world, where apparently everything has already happened, it is the movement of imagination $[\ldots]$. In the jester's attitude $[\ldots]$ what is only an option comes to fruition in order to become real before it actually exists."

${ }^{3}$ Bocheński 2009: 9 . 
Antique after Antique - in the tense "after-March" atmosphere at the end of the ' $60 \mathrm{~s}$. From the current perspective, as the writer emphasizes,

the opposition power - art which was a real theme of Naso the poet and lied at the base of Ovid's life tragedy goes beyond the quite primitive type of dispute between the Polish inteligentsia and communist party under rule of the ambitious and at the same time sore halfintelligent Gomułka of a pragmatic, puritan and ascetic soul. He was that kind of person, and I have imagined a character similar in some respects to him, although not exactly the same, of course, in the form of a punishing Jupiter-Augustus, who could not accept Ovid's constant play in erotic-moral relativism, which also was perhaps of philosophical or almost civil character, and fatally affected the Roman poet's fate and life. ${ }^{4}$

In the intentions of the author, there is thus showing, on a specific and evident example, the universal dillema of power, which strives for control all realms of the social and individual existence, and carefully observes each initiative taken in the real sphere (conspiracies, revolts, assassinations) or in the symbolic one (artistic statements involving more or less veiled critical content), since it is always assumed as the thread of a specific state of affairs considered as the ultimate, perfect, permanent, and not negotiable, so to speak, because it is identified with the so-called end of history. The poet, who presents "the age-old variability of the world," even if this thesis would be illustrated with the mythical exemplifications, becomes dangerous in this situation, because allegorical potential of his narrative suggests, therefore, falseness of conviction as for inviolability of the prevailing order of the Universe. ${ }^{5}$

In the novel entitled The Last World (1988) by Christoph Ransmayr, devoted, in a certain and short simplification, to the "cultural translation" of some fictional sequences, known from Metamorphoses, into the realities of a small contemporary town in Central Europe, that is in other words, the Black Sea Tomis located on the outskirts of the Empire - a place of exile and alleged (in the fictional frames) death of Ovid, the narrator recapitulates history of the Roman carrier and fall of the poet, in order to state that

Indeed, as the result of a scandal, his fame increased to a level of celebrity that put his name in headlines as big and bold as those for any victorious athlete and movie star. [...] And because the scandal had such fully unexpected consequences for him personally - even lottery vendors, fish and soft-drink dealers, money changers and illiterates now knew his name - the poet no longer resisted the course of events. And so he became popular. His name appeared in gossip columns. Whether a court jester or the final malicious touch to the guest list at a banquet, he was now invited into homes in which there were, to be sure, hardly any books, but plenty of marble statues, electric eyes, silver-plated fountains, and jaguar in cages. The people who lived in such homes were members not simply of society, but the society of power,

\footnotetext{
${ }^{4}$ Bocheński 2010: 174.

${ }^{5}$ See Zagórski 2006: 31-34.
} 
families whose pomp and luxury - safeguarded by dogs, glass-studded walls, armed sentries, and barbed-wire barricades - reflected the splendor of the emperor. ${ }^{6}$

The transformation of the "serious" renoma of Naso, limited earlier to the environment of experts and real lovers of poetry, into celebrity fame, to use the contemporary language, makes, indeed, a change of the poet's social position, but also attracts the Emperor's attention, or rather the state administration that represents his power. Its task is thus to clarify the meaning of gesture made by Octavian irritated with obsession of an overly zealous official, who, in the report on the course of the opening ceremony of the stadium of the Seven Mainstays, exposed the "non-orthodox" aspects of the speech made by Ovid, especially a comparison of Aegina's inhabitants turned into ants to the builders of the monumental object designed, however, for entertainment of the Roman people:

Without a word, with just the abrupt, curt motion of his hand, hardly more vigorous than if he were shaking off a housefly, Augustus interrupted the informant [...] A cursory motion of his hand. That was enough. The court needed neither complete sentences nor final judgments. In their council chambers, at their desks, and in the filing rooms of the archives, they now had a sign. Whatever was lacking for a final judgment could be appended with no difficulty. He was a poor servant of Rome who did not know how to interpret an abrupt motion of His right hand as a sign of the greatest displeasur, indeed of wrath. [...] By the way of precaution, the apparatus embraced all interpretation. The poet no longer appeared in public. The court was silent. ${ }^{7}$

Using manifestly solutions of the postmodern poetics focused on displaying the rank of anti-illusionistic writing techniques, Ransmayr, on the contrary to Bocheński, who is still obliged to reach the truth of the subject, does not even try to pretend that Naso, searched unsuccessfully in the "iron city" of Tomida by Cotta, who also attempts to find (reproduce from surviving fragments) the lost (destroyed by the author) Book of Stones (namely, Metamorphoses), is identical with the Roman poet, known to the historians and literary studies' experts under the name of Publius Ovidius Naso. Parabolic dimension of the narrative, exhibited through the transfer of the presented world into the twentieth-century realities, and by dint of the total blurring of the borderline between the fictotious and the reference order of discourse (in the depicted world, the characters with the factually certified pedegree meet the heroes from Ovid's Metamorphoses, to which they owe their original Greek names), recquires the reader to take into consideration a conventional character of the barrier between the real space and the realm of fiction, and also reminds him that freedom of use of intertextual references is a constitutive element of the repertoire of creative principles (or even obligations), which is not determined by any historical epoch along with

\footnotetext{
${ }^{6}$ Ransmayr 1990: 41, 43-44.

${ }^{7}$ Ransmayr 1990: 54, 55.
} 
its views on the rank and status of originality, genius and inspiration, and also evaluation of the artistic issues as for the influences and imitation. ${ }^{8}$

This is what Ovid was occupied with so many centuries ago, obliged to a certain extent to doing so by poetic standards, which were applicable in his times. His literary heirs, to which Bocheński and Ransmayr undoubtedly belong, seem to follow his artistic path. However, they are not alone, because the Czech writer Josef Škvorecký, also in Poland known from taking political issues and tracking of degeneration of the Communist system, joins them. In 1998, he published a novel, or rather, as he stated in the dedication for his wife Zdena Salivarová, "literary joke" entitled Nevysvětlitelný př́běh aneb Vyprávěni Questa Firma Sicula ("An Inexplicable Story or the Narrative, of Questus Firmus Siculus"). This joke was thought as a parody of editorial doings consisting of manipulation of historical truth, in order to adjust the interpretation of documents from past eras to the a priori accepted assumptions, of which "scientific" character, meaning in this case: described with the help of professional terminology, was guaranteed by the authority of well-known researchers. In the work of Škvorecki, the so-called narratio Questi, a manuscript containing a diary of the Roman citizen living in the first century of our era, which was found in the tomb of the Mayan ruler during the excavations in the famous archaeological site Copan in Honduras, is subject to similar editorial-exegetical manipulations. The author of this manuscript Questus Firmus Siculus - probably the inventor of the steam engine, which allowed him to reach Central America on the monoreme "Corrine" equipped with this engine, turns out, as it appears from his notes, to be an illegitimate son of Ovid, whose fate is treated by the author of the novel as a pretext to take the complicated intertextual game with the reader, in which indisputable facts, confirmed or verified by historiography (next to the biography of the author of Amores, there are, for example, maneuvers of the Nazi Kriegsmarine in the south Atlantic), are intermingled, interfered and connected with the echoes of literary representations of the authentic events and their absolute fictional constructs. The quasi-reliable character of these constructs, treated equally with the authoritative sources of news, maintains the impression of epistemological relativism, which is willing to consider each message to be true, as long as this truth is certified by the "trustworthy" documents that "come from the era." With regard to this, narratio Questi becomes attached to the resource of the available factual certificates, which does not fill up current

\footnotetext{
${ }^{8}$ According to Linda Hutcheon (1989: 11): "The formal linking of history and fiction through the common denominators of intertextuality and narrativity is usually offered not as a reduction, as shrinking of the scope and value of fiction, but rather as an expansion of these. Or, if it is seen as a limitation-restricted to the always already narrated-this tends to be made into the primary value, as it is in Lyotard's «pagan vision,» wherein no one ever manages to be the first to narrate anything, to be the origin of even her or his own narrative."
} 
knowledge about the Roman territorial conquests and Ovid's biography so much, as it modifies them in the total way. In this case, just like in all literary mystifications of this type, a specific argumentation technique works due to which the manuscript's authenticity (which remains incontestable in the novel ${ }^{9}$ ) is identified with the truth of information provided by him. In other words, the publishers do not give Ovid the right to fantasize, taking all his sensational revelations of which Siculus bombards the recipient at face value. All he wants is him, the recipient, to believe that Ovid, thanks to the help of Gaius Poppeus Sabinus, faked his own death, and set a comedy in Vindobona revealing the "real" causes of the delegation sentence, that is, unmasking the secret of marital infidelity of Octavian, and lived the rest of his life at the court of the British king Cymbeline, while the narrator himself was to die on the Antarctic magnetic mountain known from the work of Edgar Allan Poe under the title Narrative of Arthur Gordon Pym of Nuntucket (1838), which resulted from the never published fragment of the Icy Sphinx (1897) by Jules Verne. The writer's flippancy manifested towards individual authors and their works, including Ovid's work in the lead, forces the reader to preserve caution in "taking on faith" even the most obvious and, seemingly at least, proven facts. Literary mystification, according to Lenka Pořízková,

quite often uses the fact that the crevices in the wealth of human knowledge produce an infinite field for guesses situating on the borderline of the historical reality and the fictional creation, which, on the one hand, allows the writer for free exchange of the fictional and referential elements, but, on the other, arouses uncertainty in the reader as for the opportunity to verify information provided to him. $^{10}$

Multiplication of the intertextual links that reveals "openness of the tricks," locates, as is underlined by Katharina Volk in her monograph Ovidius, the issue of reliability of Questus' memorials in the sphere of non-sense, ${ }^{11}$ which heightens essentially postmodern conviction about the lack of ontological and epistemological difference between the fictional and factual recognition of the past, since both of them equally drown in the magmatic and undecidable

\footnotetext{
${ }^{9}$ See Škvorecký 2002: 8: "The manuscript, written in black ink on a kind of Roman paper made from Egyptian papirus known as charta fanniana (from its manufacturer, Fannius), has been subjected to every available physical tests, and its language to detailed scholarly scrutiny, since there was understandably a suspicion that it might be a hoax. After repeated tests and analyses, however, the experts concurred: it is an authentic Roman manuscript dating from the first century A. D., written in the Latin used by intellectuals in the time of Augustus."

${ }^{10}$ Poř́ízková 2014: 211.

${ }^{11}$ See Volk (2010: 125): "With his deconstruction of the notion of archaeological evidence and demonstration of the inherent intertextuality off all literature, Skvorecky far from bringing to light the truth about Ovid's exile has playfully burried it further, relegating it to the realm of mythmaking and storytelling, where it will continue to inspire more or less incredible stories."
} 
in terms of setting precise criteria for historical truth "textual sea" or rather narrative fictionalisation. ${ }^{12}$ The Czech reviewers and interpreters of the novel by Škvorecký come to similar conclusions. In this work, according to Vladimír Polách,

the logic of the investigation is dominated by joy of telling and creating the fictitious world, which at firts glance also enriches the reader's real world with new historical discoveries and commentaries. [...] In his metaliterary detective novel, Škvorecký is sometimes straightforward [...], at other times - he deliberately expresses himself in the obscurant and enigmatic way. [...] Was treason betrayal after Ovid's exile or not? And is it important at all? It is not. An Inexplicable Story clearly proves that neither life nor literature always work according to strict rules of logic and scientific knowledge. ${ }^{13}$

Incidentally, analogous conclusions could be reached by the interpreter of Ransmayr's work, since the writer constructs his "last world" on the basis of clearly defined antinomy of the fossilized Rome, which functions on the principle of absolute respecting the rational ordinances and regulations codified by the imperial policy, and the peripheral Tomis as a place "haunted" by entropy processes. Registered in apocalyptic or catastrophic spirit, the processes in question only seemingly lead to the destruction of civilization, in fact, they become a harbinger of a new cosmogony. "During the suspension of divine and natural human rights," presented in the novel, every model of reality, captured in its variability, fixed shape and operation, even the one suggested by Ovid in his Metamorphoses, seems equally likely and possible to implement, since all of them are absorbed through their cultural representations, which finally, at least on the level of perception, are prior to their real prototypes. ${ }^{14}$ Only when the artist's demiurgic gesture is fully made (the well-known "Finis coronat opus"),

${ }^{12}$ According to Pořízková (2014: 225) "when the author composes his fictional world as a sequence of possible events, which could have occurred in the crevices between historical documents, he does not really do anything else than theorists of fictitious worlds who recognize every de facto fictional narrative as a structure of possible variants of the real world".

${ }^{13}$ Polách 2008: 488-489.

${ }^{14}$ See Ransmayr (1990: 217, 218, 219): "That morning the sun rose out of a glistening sea, bathing a strange, transformed mountain landscape in the clear light. Freed of fog and clouds and advancing rain $[\ldots]$ a new mountain towered into a sky. [...] All the soundsof the heaving earth, the thunder of cascading rocks, even the soft trickle od sand had ceased. A weary silence lay over the ravines and slopes. Cotta sat alone in the workshop [...]. With a child thoughless glee he rummaged in the rags of the canopy, loosed the scribbled banners from the bindweed's blossoming tendrils and leaves, and read some of the inscriptions [...] It was right there in the tatters: Tereus was the hoopoe, Procne the nightingale, Echo was the echoing voice and Lycaon the wolf... And what flapped in the wind on the cairns of Trachila or now slid through Cotta's hands - riddles no longer - were not only past lives od the town of iron, but future destinies as well. And the name of the snowcapped peak he could see shimmering brightly through the broken window was also recorded on the rags: Olympus. [...] here Naso had walked. This was Naso's path. Banned from Rome, the realm of necessity and reason, the poet had finished his Metamorphoses beside the 
Naso had freed his world of human beings, of their rules and regulations [...] His Greek servant had written down his tales and erected a monument to every word he spoke - but that was meaningless now [...]. The books mildewed, burned, turned to ashes and dust [...] and even letter chiseled in basalt vanished under the patience of slugs. Reality, once discovered, no longer needed recording. ${ }^{15}$

Comparing versions of the subject, namely, Ovid's life, offered to the reader by Ransmayr and Bocheński, Mieczysław Dąbrowski concludes that:

The both writers construct their texts in accordance with postmodern aesthetics, however, Ransmayr translates Ovid's Matmorphoses in an ideological sense in order to achieve historiosophical and metaphysical effect refering to tragic experiences of the twentieth century, while Bocheński goes in the direction of the politicization of the text. Since he does not want to be perceived as an obscurant and biased writer of his epoch (praiseworthy intuition, in any case), Bocheński additionally equips his character with philosophy of art, bitter and risky appointment of the artist, value of poetic word, etc., which are older than all totalitarian systems. In the both cases, the history of Rome and Ovid's text are parodied, but not annihilated, since they serve as a convenient frame for the writer's own images and resentments. ${ }^{16}$

On the margin of consideration, one should place the thesis of dubious rightness, according to which Ransmayr's novel is not marked by political commitment, but also the issue of affinity of Naso the Poet with postmodernism: such hypothesis built only on the basis of the exposed intertextuality of the narrative seems, therefore, an exaggerated example of the interpretative presentism, especially that the "strategy of actualization," used in fictionalisation of the past, was analysed years ago by Kazimierz Bartoszyński. ${ }^{17}$ At this point, it is worth observing the relationship between knowledge provided by documentary sources and research of historians or experts in literary studies and their transformation or modification, which results in fictionalisation. All the works in question inscribe themselves into this current of historical literature (or biographical literature), which makes use of "white spots of history" in order to carry out amplification operations of various types, and, above all, to formulate suppositions serving various aims, often distant from honest access to the truth, and to "test" operational suitability of different variants of the so-called counterfactual fiction. ${ }^{18}$ This strategy is

Black Sea, transforming this barren craggy coast, where he froze and ached with homesickness, into his coast, transformig those barbarians, who harassed and drove him into forsaken world of Trachila, into his characters."

${ }^{15}$ Ransmayr 1990: 219.

${ }^{16}$ Dąbrowski 2014: 103.

${ }^{17}$ Cf. Bartoszyński 1991: 87.

${ }^{18}$ Bartoszyński (1991: 81) thus claims that: "Facing poverty of knowledge and historical sources, and also in cases of their non-use or deliberate omission [...], the interpolation function grows, and the phenomenon of domination of literary and genre structures over elements intended 
undoubtedly supported with fragmentariness of information concerning Ovid's biography left by his witnesses, especially the intriguing and still unresolved mystery as for the causes of his exile, which might be intentionally maintained by the instruments controlling cultural and historical memory (or rather forgetting) ${ }^{19}$ Writing about the motifs that made him to choose the author's Ars amandi fate as the subject of his fictional reconstruction, Jacek Bocheński emphasizes that his character is "A wonderful artist, pure form and phantasy, biographical puzzle, man without documents, so to speak, existing in his own poetry - it was a temptation". ${ }^{20}$

And exactly this existence through or "in" his poetry results in the procedure, as effective (and attractive) as for many reasons problematic, which consists in the (auto)biographical interpretation of the Roman poet's works. This interpretation comes down to tracking traces, specific enclaves of referentiality hidden behind various masks, pseudonyms, and mythical plots, which are perceived as ciphers intended for decoding by initiated cryptologist. ${ }^{21}$ This is the role for the writers, or rather the narrators created in their works, not by accident reaching for literary genre patterns of detective novel, ${ }^{22}$ which disposes

for literary "taming" appears. In such a situation, one can talk about lower adequacy of the modelling image, and at the same time, however, significant (although easy to challenge) ability to formulate explanatory hypotheses." Anna Lebkowska (2003: 33) demonstrates that unveiling a fictitious dimension of the biographical narratives causes that "they may have some adverse effect on the ontological status of the world, in which the life of the character of the novel is rolling. I do not mean either novels reconstructing a biography and placing fictitious additions, »dialogues, thoughts, characters « within the fictional tale [...], or a narrative based on revealed hypotheses. I am limiting myself only to authentic figures' biographies, created within fiction, which are presented in a manner totally discordant with generally known facts [...]. Introduction of a biography into the worlds possible - counterfactual as well as hypothetical - takes place in consultation with the recipient. [...] One does not need to add that this type of biographies are linked with a variety of novel called a historiographical metafiction."

${ }^{19}$ See Ankersmit (1989: 146): "When his intelligent interviewer Guy Lardreau asks him what constitutes for him, Duby, the most interesting evidence, he says that this can be found in what is not said, in what a period has not said about itself, and he therefore compares his historical work with the developing of a negative. Just as the fish does not know that it is swimming in the water, what is most characteristic of a period, most omnipresent in a period, is unknown to the period itself. It is not revealed until a period has come to an end. The fragrance of a period can only be inhaled in a subsequent period. [...] However, the point here is Duby's observation that the essence of a period is determined by the destinataire, to use the term of the French postmodernists, by the historian who has to develop here and now his negative of a period from that which was not said or was only whispered, or was expressed only in insignificant details."

${ }^{20}$ Bocheński 2007: 157.

${ }^{21}$ However, it should be noted that such a procedure is also not foreign to classical philologists. See: Wesołowska 2006: 51-62.

${ }^{22}$ Even The Last World is sometimes referred to as a metaphysical thriller - see: Marciniak 2006: 321-328. 
of tools facilitating a fictional investigation. ${ }^{23}$ Bocheński as well as Škvorecký (except for Ranmayr who, as it was already mentioned, is interested to a minimal extent in the reconstruction of Ovid's authentic biography) are aware of the dangers resulting from such a "translating fiction into realities," that is in other words, a reversal of direction (order) of literary modelling of the world, which, inevitably, weakens the conviction of authoritative character of the information, thus recovered, and allows them to move the whole issue into a space of thought in the field of philosophy or literary axiology:

And yet the moment is finally coming when the fantasy must feed on reality. If not, end of story, as I - being an announcer - would say. There will not be any story without fact, there will not be any idea without opportunity [...], the idea will be born from circumstances, yes, illusionist, [...] local circumstances and material circumstances, for the idea can come only from the very thing, the thing! [...] If by chance they are among you representatives of the scientific world (and I mean the experts in Ovid which I welcome with respect) [...], you will perhaps agree with me, a modest humble announcer, that man does not live on conventionalities alone, because the poet is also a man. And you professors will perhaps agree that the poet personally experiences this or that, and not only repeats other people's relations following the authors more polished in life. ${ }^{24}$

${ }^{23}$ Lubomír Doležel (2008: 122), world-renowned expert in the theory of possible worlds, claims that "The main inspiration for the counterfactual fiction is popular literature, especially in the form of sensational and adventure genres."

${ }^{24}$ Bocheński 2009: 62-63. In the aforementioned book Antiquity after Antiquity, Bocheński describes more precisley problems accompanying the process of deriving "material information" from the poet's work, reminding on this occasion that the right to use freely someone else's word was recovered by the creators only in the atmosphere of postmodernism (through the so-called "postmodern turn"): "In the case of Ovid, the only source of all biographical information might be only his poems because we do not have any other material. [...] I want to emphasize one thing: to tell about the life of Nazo the poet means a necessity of summarizing his poetry in our own words. But is it allowed to act in this way with poetry? Today such a question seems ridiculous. Converting, cutting into pieces, parody, persiflage, collage, various adaptations of literary, plastic or musical canon, starting unceremoniously with Shakespeare, Leonard, Mozart, inluding Ovid, especially as the author of Ars amandi, is a routine now, often an entertaiment trivia. 50 years ago other manners in culture were valued. [...] There is, however, a danger, which I have not yet accustomed with. Philologists, literary experts, and historicians of literature agree in the opinion that Ovid's poetry, even if it presents the suggestive, realistic scenes from life whose character is to be their author, does not authorize for inference as for the poet's real experience, because he, in accordance with the conventions of the then art, was processing literary motifs derived from the Greeks, which were not his personal benefits. If I oppose this view [...] and adhere to my position that one man's biography might be derived from his poetry based on the play of topoi, I will only confirm a suspicion, incumbent uopn me for a long time, that is: I am really clever literary manipulator with no taste and reliable knowlegde, who does not only uses antique in order to get publicity streaked with political ambiguities, and summarizes ancient geniuses with his own words, but also constructs an untrue biography of one of them and, by doing so, falsificates history of literature. Never mind the suspicion. How am I going to get out of the real problem of unbelievable historical sources, wihout which I will not create a biography?" (Bocheński 2010: $156,158)$. 
In the novel by Škvorecký, also based on the attempt of "uncovering" content hidden behind the "cultural prefabricates," from which Ovid, as an expert connoisseur of poetic craft, assembled his works on the principle of almost mathematical combinatorics, the cognitive dillemas accompanying interpretation of his individual texts in the manner of Lejeune's "autobiographical pact," are just as strong, if not even stronger, explicated. In the "specialist comments," posted in the novel, which are to explain the "secrets" of Narratio Questi, his publisher Patrick Oliver Enfield (the initials are obviously not accidental) states that:

Life in a "barbarian" environment would understandably have driven the poet, accustomed to the amenities of civilized Rome, to the brink of desperation, which apparently led him to overstate the hardships of his life in the climate of Tomis. For a Roman, the only discomfort in the coastal town would have been its winter season, however brief. The long spring and summer there are known to have been more than pleasant. [...] So Ovid's friends (and some modern scholars as well) may be justified in concluding that Ovid presented Tomis as being worse than it was. In fact, some go so far as to deny that Ovid ever lived there (...). One of the arguments for this theory is raised by the Ovid's friends as well (Scr. 3, Frg. 9). Scholars have meticulously compared Ovid's climatic, geographical, and ethnographic references to Tomis and its inhibitants with similar references by older poets (Virgil, Homer), who demonstrably had never been there, and have found marked similarities between Ovid's observations and those of the classics. [...] Be that as it may, I am convinced that Questus is justified when he dismisses the arguments of his friends [...] and concludes that "when the spirit is in pain, so is the body." 25

In the novels by Bocheński and Škvorecký, the biography of the poet, reconstructed on the basis of the careful interpretation of his poems, interpretation which remains sensitive to all nuances of meaning, turns out, therefore, to be an "imaginery biography" adjusted (well-fitting) to the needs of the present that respects the "horizon of expactations" of the reader and indicates these faces of ancient centuries which have not lost their relevance so far, and due to this they, in provocatives terms of Richard Rorty, can still be used for the recipient's own purposes. ${ }^{26}$ Writing about the breakup of the so-called great narratives founded on the teleological conception of the historical process, and using the "dendrological" metaphor of history perceived in the form of trunk, branches and leaves, Frank Ankersmit states that:

What remains now for Western historiography is to gather the leaves that have been blown away and to study them independently of their origins. This means that our historical consciousness has, so to speak, been turned inside out. When we collect the leaves of the past (...), what is important is no longer the place they had on the tree, but the pattern we can form from them now, the way in which this pattern can be adapted to other forms of civilization

\footnotetext{
${ }^{25}$ Škvorecký 2002: 107-108.

${ }^{26}$ Cf. Rorty 2008: 120 .
} 
existing now. (...) We must not shape ourselves according to or in conformity with the past, but learn to play our cultural game with it. ${ }^{27}$

Such a game, on the one hand, with the vision of reality fixed in Ovid's poetry, and, on the other, with the reader, is played by Škvorecký, Ransmayr and Bocheński. Only it is worth remembering that participation in this game requires disposal of resources composed of specific erudite competences. Therefore, a question arises about the level of Ovid's presence in the contemporary cultural memory, and, in consequence, how the modern recipient deals with various cognitive pitfalls pledged by writers, especially that, as Lenka Pořízková points out, historical narratives have already lost their "education mission," and "postmodern fiction is conceived as a device of testing or relativizing the reader's knowledge, above all through mystification." ${ }^{28}$ Taking into consideration a pragmatic dimension of intertextual relationship, Michał Głowiński proves that:

In equal measure, the subject of the appeal is what is known and what is unknown, hence the chance of noticing its presence is different in every case. But this does not mean that references to less known texts are less important or that they are only an example of futile operation which does not count with the real impact of the work. One cannot enter such differentiations, all the more that the criteria of what is "known" and "unknown" would be impossible to determine, which would be followed by the immediate question: "known" - but to whom? ${ }^{29}$

In the essay entitled Noster, delivered as a preliminary word during the conference Ovid: Work, Reception, Legend, Jacek Bocheński complains that:

We stopped learning Latin, we stopped writing Latin, think, feel, make music and sing in Latin [...], in the twentieth century, Latin did not stand the deadly pace of changes, and above all it did not hold the catastrophy resulting from eurocentrism, which has significantly weakened demand for Latin in the contemporary world. ${ }^{30}$

A similar pessimistic diagnosis as for the decline of traditional humanistic education has encouraged a Czech classical philologist Anežka Vidmanová to fortmulate conclusion according to which: .

At the time of writing his novel, Škvorecký with no doubt had a great fun. The humorous dimension of his vision will be, however, appreciated only by some of his contemporaries those among of the 70 years-old who have a humanistic education. People who, for example, write qui bono, qui prodest, instead of cui bono, cui prodest will hardly be able to discover this writer, although they will be still amused by other litterary allusions present in his text. ${ }^{31}$

\footnotetext{
${ }^{27}$ Ankersmit: 150, 151.

${ }^{28}$ Pořízková 2014: 212.

${ }^{29}$ Głowiński 1992: 115.

${ }^{30}$ Bocheński 2006: 19, 21.

${ }^{31}$ Vidmanová 1999: 557.
} 
The writers in question attempt differently to deal with the problem of noncommuniactiveness and omission of the most important cultural message of their novels: Bocheński introduces a conditional narrative mode and presents unverified information as included in bracketts revealing by this his own creative workshop and admitting not once to epistemological failure; Škvorecký smuggies reliable information in the quasi-sientific discourse of the manuscript's editors (their shelling belongs to the recipient's flooding), and additionally provides the text with the postword, while Ransmayr puts an annex in his work, in which he compares in a dictionary form the characters from Metamorphoses and The Last World, who share the identical names, and quotes the whole fragments from Ovid's work. The essence of this literary message comes down, therefore, to timeless indestructiblity of the poetical truth, which, as Bocheński argues

was turning into the truth from every position, into the truth of thoughts and feelings, obviousness and paradox, experience and belief, fact and myth, into the truth of the past and the future, into universal truth. He was a poet because he discovered his own way to write the truth which was to live THROUGH THE AGES. ${ }^{32}$

In one of his rare "islets of seriousness," scattered in the sea of the writer's metaliterary intertextual phantasmagoria, Josef Škvorecký does not hesitate, through the words of the protagonist, to express tribute to the immortal greatness of the creator, who managed, and this is given only to a few, to leave his lasting mark on the memory of posterity:

I recalled the line from his collegue's trite poem, "I have built the minument..." But he... I raised the book to my eyes and, in Aurora faint light, I read, "Could my poems have made her a public figure? [...] I've pimper her charms, I've marked up the route for lovers..." I felt as if I were walking the route he had indicated and in Aurora's light it dawned on me that someday the only thing left of Proculeia would be those lines of poetry. Time and the elements would turn racimachos's exquisite sculpture to dust. Some stranger would buy Caecina's house, other sculptures would grace the atrium, Proculeia's bust would wind up in the garden, wars would roll through Rome, a Hannibal wouldn't stop at the gates of the city, some soldier would carry it off to Africa, or Persia, or Britain, the boat would sink and the statue would come to rest in the mire at the bottom of the sea. I sighed. "Pimped her charms..." Horace, Propertius, Tibullus, Catullus, thanks be to the gods that Rome has such pimps. ${ }^{33}$

Trans. by A. M. Skibska

\section{BIBLIOGRAPHY}

Ankersmit 1989: Ankersmit, F. R. 1989. "Historiography and Postmodernism." History and Theory 2 (1989): 137-153.

Bartoszyński 1991: Bartoszyński, K. 1991. Powieść w świecie literackości. Szkice. Warszawa.

\footnotetext{
${ }^{32}$ Bocheński 2009: 263-264.

${ }^{33}$ Škvorecký 2002: 71-72.
} 
Bocheński 2006: Bocheński, J. 2006. “Noster.” In Owidiusz. Twórczość, recepcja, legenda. Ed. by B. Milewska-Waźbińska, J. Domański, 17-23. Warszawa.

Bocheński 2009: Bocheński, J. 2009. Nazo poeta. Warszawa.

Bocheński 2010: Bocheński, J. 2010. Antyk po antyku. Warszawa.

Dąbrowski 2014: Dąbrowski, M. 2014. "Dwa przypadki kulturowego przekładu Owidiusza: Juliusz Bocheński, Nazo poeta i Christoph Ransmayr, Die letzte Welt." Rocznik Komparatystyczny 2014: 85-104.

Doležel 2008: Doležel, L. 2008. Fikce a historie v období postmoderny. Praha.

Głowiński 1992: Głowiński, M. 1992. Poetyka i okolice. Warszawa.

Hutcheon 1989: Hutcheon, L. 1989. "Historiographic Metafiction. Parody and Intertextuality of History." In Intertextuality and Contemporary American Fiction. Ed. by P. O'Donnell, R. C. Davis, 3-32. Baltimore.

Kołakowski 1989: Kołakowski, L. 1989. "Kapłan i błazen (rozważania o teologicznym dziedzictwie współczesnego myślenia)." In Kołakowski L. Pochwała niekonsekwencji, vol. 2, 161-180, Londyn.

Łebkowska 2003: Łebkowska, A. 2003. "Narracja biograficzna w fikcji.” Teksty Drugie 2-3 (2003): 28-40.

Marciniak 2006: Marciniak, K. 2006. "Metamorfozy jako thriller metafizyczny. Owidiusz według Christopha Ransmayra.” In Owidiusz. Twórczość, recepcja, legenda. Ed. by B. MilewskaWaźbińska, J. Domański, 321-328. Warszawa.

Polách 2008: Polách, V. P. 2008. “Josef Škvorecký: Nevysvětlitelný př́běh aneb vyprávění Questa Firma Sicula." In V souřadnicich volnosti. Česká literatura devadesátých let dvacátého století v interpretacích. Ed. by P. Hruška, L. Machala, L. Vodička, J. Zizler, 486-492. Praha.

Pořízková 2014: Pořízková, L. 2014. Přátelský podvod. Mystifikace (nejen) v české literatuře 20. století. Praha.

Ransmayr 1990: Ransmayr, C. 1990. The Last World. A novel with the Ovidian repertory. Transl. by J. E. Woods. New York.

Rorty 2008: Rorty, R. 2008. “Kariera pragmatysty.” In Interpretacja i nadinterpretacja. Ed. By S. Collini. Transl. by T. Bieroń, 101-123. Kraków.

Škvorecký 2002: Škvorecký, J. 2002. An Inexplicable Story or the Narrative of Questus Firmus Siculus. Transl. by K. Poláčková Henley. Toronto.

Vidmanová 1999: Vidmanová, A. 1999. "Škvoreckého postmoderní antika." Česká literatura 5 (1999): 553-558.

Volk 2010: Volk, K. 2010. Ovid. West Sussex.

Wesołowska 2006: Wesołowska, E. 2006. "Pasowanie się z czasem - poeta w Fasti. Rekonesans." In Owidiusz. Twórczość, recepcja, legenda. Ed. by B. Milewska-Waźbińska, J. Domański, 51-62. Warszawa.

Zagórski 2006: Zagórski, M. 2006. "Polityczny aspekt Metamorfoz w kontekście programu poetyckiego Owidiusza." In Owidiusz. Twórczość, recepcja, legenda. Ed. by B. MilewskaWaźbińska, J. Domański, 31-41. Warszawa.

\title{
WHY OVID? POSTMODERN ALTERNATIVE BIOGRAPHIES OF THE GREAT POET
}

\author{
Sum mary
}

Postmodern writers' preference for proposing the counterfactual versions of history, the elimination of its „white spots" and ,places of understatement” or the use of the hypothesis regarding the theory of possible worlds are commonly known. Selection of topics, characters and events developed by the writers, in order to cast doubt on established certainties, undermine 
uniqueness of the facts and reject ,valid” interpretations of history, turns out to be less obvious activity. The fate and work of Ovid belong to those constantly returning theme resources, of which clearly visible presence allows the writers to perform various operations within creative fiction, and to expose the anti-illusionist character of narrative. The reasons for this turn towards the biography of the author of Metamorphoses seem varied and complex, since they include granting him status of patron/prototype of all artists losing the struggle for freedom of expression in a dispute with the mighty power, finding in his poetry „modern” threads and ways to recognize reality which arouse surprise and cognitive anxiety, fascination with exile and death mystery. These motivations perpetuate and overlap, for example, in the novels Naso the Poet (1969) by Jacek Bocheński, An Inexplicable Story or the Narrative of Questus Firmus Siculus by Josef Škvorecký (1998) and The Last World. A Novel with an Ovidian Repertory by Christoph Ransmayr (1988). 